\title{
LITERATUR REVIEW: TERAPI NON FARMAKOLOGIS UNTUK MENINGKATKAN KUALITAS TIDUR PASIEN DI ICU ATAU CCU
}

\section{Literatur Review: Non-Pharmacological Therapy for Increasing Sleep Quality of Patients in ICU or CCU}

\section{Rizky Asta Pramestirini, Heny Ekawati, Suhariyati}

Program Studi S1 Keperawatan Universitas Muhammadiyah Lamongan

\section{Riwayat artikel}

Diajukan: 18 Agustus 2021

Diterima: 31 Agustus 2021

\section{Penulis Korespondensi: \\ - Rizky Asta \\ Pramestirini \\ - Universitas \\ Muhammadiyah \\ Lamongan \\ e-mail: \\ rizkyastapramesririni@gm ail.com}

\section{Kata Kunci:}

eye mask, earplug, music, ICU/CCU, kualitas tidur

\begin{abstract}
Abstrak
Pendahuluan : Tidur adalah salah satu kebutuhan dasar manusia. Kualitas tidur yang baik dapat meningkatkan perbaikan dari penyakit. Gangguan tidur biasa terjadi pada pasien rawat inap di CCU dan ICU. Untuk mengatasi gannguan tidur dapat diberikan terapi farmakologis seperti benzodiazepine, non-benzodiazepine. Tujuan: Membandingkan beberapa hasil penelitian tentang terapi non farmakologik (eye mask, earplugs, terapi musik, mematikan lampu, modifikasi lingkungan) dalam meningkatkan kualitas tidur untuk menentukan tindakan keperawatan terbaik dan aman untuk mengatasi gangguan tidur pasien. Metode: Pencarian artikel menggunakan PICO framework di database; Google Scholar, Ebscho, Science direct, Elseiver, MedLine, CINAHL, PubMed, dan ProQuest, dibatasi rentang 10 tahun terakhir; 2011 s/d 2021, didapatkan 10 Jurnal Internasional. Hasil: Review menunjukkan jadwal di luar waktu tidur, dan kombinasi. Hasil review menunjukkan tindakan yang paling efektif diterapkan secara lokal untuk meningkatkan kualitas tidur yaitu menurunkan pencahayaan dan kebisingan serta pengalihan jadwal perawatan di luar jam tidur karena mudah, aman, dan tidak membutuhkan biaya. Bila intervensi tersebut belum membantu dapat ditawarkan eye mask, earplugs, dan atau musik sesuai dengan pilihan pasien, budaya setempat, dan fasilitas yang tersedia di rumah sakit.. Kesimpulan: Diperlukan penelitian lanjutan pada pasien diluar ICU/CCU dengan jumlah sampel lebih banyak, karakteristik usia dan kondisi yang berbeda, durasi perlakuan lebih lama, dan menggunakan alat ukur kualitas tidur objektif seperti polysomnography.
\end{abstract}

\footnotetext{
Abstract

Background: Sleep is one of the basic human needs. Good quality sleep can increase the improvement of the disease. Sleep disturbances are common among hospitalized patients in CCU and ICU. To overcome sleep disturbances, pharmacological therapies such as benzodiazepines, non-benzodiazepines can be given. Objective: To compare several research results on non-pharmacological therapies (eye masks, earplugs, music therapy, turning off lights, environmental modifications) in improving sleep quality to determine the best nursing action and safe for treating sleep disorders patients. Method: Search articles using the PICO framework in the database; Google Scholar, Ebscho, Science direct, Elseiver, MedLine, CINAHL, PubMed, and ProQuest, limited to the last 10 years; 2011 to 2021, 10 International Journals were obtained. Results: The results of the review show schedules outside of bedtime, and combinations. The results of the review show that the most effective actions applied locally to improve sleep quality are reducing lighting and noise and diverting treatment schedules outside of bedtime because it is easy, safe, and does not cost money. If the intervention has not helped, eye masks, earplugs, and/or music can be offered according to the patient's choice, local culture, and facilities available at the hospital. Conclusion: : Further research is needed on patients outside the ICU/CCU with a larger number of samples, different age and condition characteristics, longer treatment duration, and using objective sleep quality measurement tools such as polysomnography.
} 


\section{PENDAHULUAN}

Tidur adalah salah satu kebutuhan dasar manusia untuk mengembalikan kesehatan, energi dan kesejahteraan fisik. Pada saat tidur, hormon tertentu seperti serotonin dan growth hormon akan mengalami perubahan kimia dan peningkatan nutrisi seluler. Hasil studi di Shahrekord-Iran, menyatakan sekitar $51 \%$ dari pasien gagal jantung kongestif mengalami gangguan tidur (Babaii, Atye, et.al., 2015). Gangguan tidur biasanya dipengaruhi beberapa faktor antara lain; faktor lingkungan (suara/keramaian), pencahayaan terus menerus, aktivitas perawatan 24 jam, ketidaknyamanan/nyeri, isolasi, aktivitas pengobatan dan stres psikologi terkait penyakit yang mengancam kehidupan atau komplikasi dari penyakit (Li, S.Y., et.al., 2011). Upaya meningkatkan kualitas tidur pada pasien ICU maupun CCU merupakan hal penting karena dapat menyebabkan peningkatan risiko infeksi, komplikasi, prolonged hospital stay dan mortalitas (Li, Shu-Yen, et.al., 2011). Penggunaan obat-obatan sedatif dan hipnotik dapat meningkatkan kualitas tidur secara signifikan, namun dapat menimbulkan berbagai macam efek samping (Babaii, Atye, et.al., 2015). Terapi komplementer (terapi musik, penggunaan eye mask, earplugs, modifikasi lingkungan dan tindakan keperawatan) juga dapat meningkatkan kualitas tidur tanpa efek samping yang serius (Saeedi M. et.al., 2012; Jones C et.al., 2012). Berbagai penelitian telah dilakukan untuk menjelaskan pengaruh penggunaan terapi nonfarmakologi terhadap kualitas tidur pasien yang dirawat di CCU/ ICU. Namun masih terdapat beberapa keterbatasan seperti; metode, rentang waktu, ruang lingkup, alat ukur, dan populasi penelitian sehingga belum cukup menyimpulkan pengaruh penggunaan terapi non farmakologi terhadap kualitas tidur pasien dengan yang dirawat di ICU / CCU. Tujuan studi ini yaitu melakukan literature review tentang efektifitas terapi nonfarmakologi (eye mask, earplugs, terapi musik, mengurangi pencahayaan, modifikasi suara kebisingan lingkungan, pengalihan jadwal perawatan di luar jam tidur) terhadap kualitas tidur, membandingkan hasil penelitian terhadap persamaan, kelebihan, dan kekurangan masingmasing penelitian untuk disimpulkan mana intervensi terbaik yang bisa diterapkan secara lokal, serta menentukan gap penelitian sebagai saran penelitian selanjutnya. Literatur review ini disajikan dalam bentuk artikel yang terdiri dari; abstrak, pendahuluan, metode, hasil dan pembahasan, implikasi terhadap praktik, kesimpulan, daftar pustaka, dan lampiran.

\section{METODE}

Literature review diawali dengan pencarian artikel menggunakan PICO framework. Populasi jurnal yang direview yaitu pasien ICU atau CCU. Intervensi yang dilakukan berupa pemasangan eye mask dibandingkan dengan; earplug, terapi musik, pengurangan pencahayaan, pengurangan suara kebisingan, dan atau kombinasi yang dapat meningkatkan kualitas tidur secara signifikan. Keyword yang digunakan; eye mask, earplugs, music, noise, dan sleep quality pada database Google Scholar, Ebscho, Science direct, Elseiver, Medline, CINAHL, PubMed, dan ProQuest. Hasil pencarian didapatkan 42 artikel kemudian ditelaah kritis yang menyisakan 10 Jurnal Internasional dengan 9 desain RCT (Randomized Controlled Trial) dan 1 quasi eksperimen.

\section{HASIL DAN PEMBAHASAN}

1. Eye mask, Terdapat tiga penelitian yang dilakukan untuk membuktikan efektifitas eye mask terhadap peningkatan kualitas tidur pada pasien jantung di CCU di rumah sakit yang berbeda di Iran meliputi; Mohammad Daneshmandi, et.al. (2012), Mashayekhi, et.el. (2013), dan Atye Babaii, et.al. (2015) dengan menggunakan desain RCT (level 2 dari 7 level of evidence) pada 60 pasien jantung usia $>18$ tahun. Dua penelitian menggunakan alat ukur PSQI (Petersburg's Sleep Quality Index) dan 1 menggunakan VSH (Verran and SnyderHalpern Sleep Scale. Hasil ketiga penelitian tersebut menunjukkan bahwa eye mask dapat meningkatkan kualitas tidur pada pasien jantung secara signifikan. 
Tabel 1: Hasil studi literatur terapi non farmakologik (eye mask, earplugs, terapi musik, mematikan lampu, modifikasi lingkungan) dalam meningkatkan kualitas tidur Judul, Author, tahun Intervensi, Sampel,\& Teknik Sampling

\section{Alat Ukur Desain}

PSQI RCT

Effect of Using Eye mask on sleep quality in Cardiac

patients: Randomized controlled

trial

Ateye Babaii, et al. 2015 Eye mask

$\mathrm{N}=60$ usia $47-69$ thn,

dibagi menjadi 2, tidak ada yang drop

Teknik sampling :

Random

Effect of eye mask on sleep quality in patient't with acute coronary syndrome.

Mohammad danesh mandi, et.al.2012

Intervensi :

Eye mask

$\mathrm{N}=60$ usia $>18$ thn

(Petersburg's

Sleep Quality

Index)

RCT

Penggunaan eye mask dapat meningkatkan kualitas tidur pasien jantung dengan

signifikan

$(\mathrm{p}<0,05)$

Teknik sampling:

Random

The Effect Of Eye Mask on

Sleep Quality in Patient of

Coronary Care Unit.

Masyhayekhi, F. Et.al.2013

Intervensi :

Eye mask

$\mathrm{N}=60$ usia $>18$ tahun

Dibagi 2, masing-masing 30

Tidak ada yang drop

Teknik sampling :

Random

The Effect of earplugs on sleep
quality in patients with acut

coronary syndrome.

Fateme Neyse, et.al.2011

\section{Intervensi :}

Earplugs

$\mathrm{N}=60$ Dibagi 2

Teknik sampling:

Random

Efficacy of Controlling Night

time noise and activities to

Intervensi:

improve patient's sleep quality

in a surgical intensive care unit

Shu - Yen Li, et al.2011

$\mathrm{N}=60$, drop 5

Usia > 18 tahun

Teknik Sampling:

Tidak dijelaskan

The Effect of Earplugs and Eye

\section{PSQI}

(Petersburg's

Sleep Quality

Index)

RCT

Pengguanaan eye mask dapat

meningkatkan kualitas tidur pada pasien

dengan ACS

$(\mathrm{p}<0,05)$

\section{Verran and}

Snyder-Halpern

Sleep Scale (VSH

Sleep Scale)

RCT

Penggunaan eye mask selama tidur malam meningkatkan meningkatkan kualitas tidur dengan signifikan $(\mathrm{p}<0,05)$

PSQI

(Petersburg's

RCT

Penggunaan Earplugs dapat meningkatkan Index)

SICUQ,

RCSQ

(Richards

Quasi

Hasil penelitian menunjukkan bahwa

Campbell Sleep

Questionnaire)

and decibel meter

VSH

Eksperim mengurangi stimulus lingkungan dapat

ental meningkatkan tidur pada pasien di

Surgical ICU

RCT

Pemaikaian eraplug dan eye mask
Sleep Quality 
Jurnal Ilmiah Keperawatan (Scientific Journal of Nursing), Vol 7, No 2, Tahun 2021

\begin{tabular}{|c|c|c|c|}
\hline $\begin{array}{l}\text { Mask on Patients Percceived } \\
\text { Sleep Quality in Intensive Care } \\
\text { Unit } \\
\text { Ahmad Reza Yazdannik, et al. } \\
2014\end{array}$ & $\begin{array}{l}\text { Earplug + eye mask } \\
\mathrm{N}=50 \text { ( dibagi dua, usia }>18 \text { tahun) } \\
\text { Teknik Sampling : Random }\end{array}$ & $\begin{array}{l}\text { (Verran \& } \\
\text { Synder-Halpen } \\
\text { Sleeping Scale) }\end{array}$ & $\begin{array}{l}\text { memiliki efek positif pada kualitas tidur } \\
\text { pasien yang dirawat di ICU. }\end{array}$ \\
\hline $\begin{array}{l}\text { Effect of Earplugs and Eye } \\
\text { Masks on Perceived Quality of } \\
\text { Sleep During Night among } \\
\text { Patients in Intensive Care Unit } \\
\text { Mr. Koushal Dave, et al.2015 }\end{array}$ & $\begin{array}{l}\text { Intervensi : } \\
\text { Earplug + eye mask } \\
\mathrm{N}=50 \text { (dibagi dua, usia } 20-70 \text { tahun) } \\
\text { Teknik Sampling: } \\
\text { Random }\end{array}$ & $\begin{array}{l}\text { RCSQ } \\
\text { (Richards } \\
\text { Campbell Sleep } \\
\text { Questionnaire) }\end{array}$ & $\begin{array}{l}\text { Lebih dari } 70 \% \text { partisipan mengemukakan } \\
\text { bahwa earplug dan eye mask nyaman } \\
\text { digunakan dan meningkatkan kualitas tidur } \\
\text { mereka. }\end{array}$ \\
\hline $\begin{array}{l}\text { Effects of earplugs and eye } \\
\text { masks combined with relaxing } \\
\text { music on sleep, melatonin, and } \\
\text { cortisol levels in ICU patients: a } \\
\text { RCT. } \\
\text { Rong-Fang Hu, et al. } 2015\end{array}$ & $\begin{array}{l}\text { Intervensi : Eyemask+earplugs+music } \\
\text { Sampel } 50 \text { pasien usia } \geq 40 \text { thn, } 20 \text { responden klp intervensi } \\
\text { dan } 25 \text { responden klp kontrol, } 5 \text { responden drop } \\
\text { Teknik sampling: } \\
\text { Random }\end{array}$ & $\begin{array}{l}\text { RCSQ } \\
\text { (Richards- } \\
\text { Campbell sleep } \\
\text { questionare) }\end{array}$ & $\begin{array}{l}\text { Kualitas tidur yang lebih baik pada } \\
\text { kelompok intervensi. tidak ditemukan } \\
\text { perbedaan pada kortisol dan melatonin } \\
\text { pada urin pasien sebelum dan setelah } \\
\text { tindakan pembedahan }\end{array}$ \\
\hline $\begin{array}{l}\text { Effect of sleep-inducing music } \\
\text { on sleep in persons with } \\
\text { percutaneous transluminal } \\
\text { coronary angiography in the } \\
\text { Cardiac Care Unit. } \\
\text { Min-Jung Ryu, et.al. } \\
2011\end{array}$ & $\begin{array}{l}\text { Intervensi : } \\
\text { Grup eksperimen: } \\
\text { Eyeshield+Earplugs + music } 52 \text { menit dimulai pkl } 10 \text { pm } \\
\text { Grup Kontrol : } \\
\text { Eyeshiel+earplugs+No Music } \\
\mathrm{N}=60 \text {, drop 2, } \\
\text { usia } \geq 20 \text { thn } \\
\text { Teknik sampling: } \\
\text { Random }\end{array}$ & $\begin{array}{l}\text { VSH } \\
\text { (Verran \& } \\
\text { Synder-Halpen } \\
\text { Sleeping Scale) }\end{array}$ & $\begin{array}{l}\text { Pemberian musik pada pasien PTCA } \\
\text { menunjukkan terjadi peningkatan kualitas } \\
(\mathrm{p}<0.001) \text { dan kuantitas }(\mathrm{p}=0.002) \text { tidur } \\
\text { secara signifikan }\end{array}$ \\
\hline $\begin{array}{l}\text { Effect of oral melatonin and } \\
\text { wearing earplugs and eye masks } \\
\text { on nocturnal sleep in healthy } \\
\text { subjects in a simulated ICU } \\
\text { environment. } \\
\text { Hua-Wei Huang, et al. } \\
2015\end{array}$ & $\begin{array}{l}\text { Intervensi : } \\
\text { Part I : Noise + Light vs Quite + Light Off } \\
\text { Part II : Noise + Light vs NL + Placebo vs NL+Melatonin vs } \\
\text { NL+Earplugs+eyemask } \\
\text { Sampel } 40 \text { orang sehat usia > } 18 \text { tahun, } \\
\text { Teknik sampling : } \\
\text { Random } \\
\text { Part I : Dibagi } 2 \text { (20 vs } 20) \\
\text { Part II : Dibagi } 4 \text { (masing - masing } 10) \\
\end{array}$ & $\begin{array}{l}\text { PSG } \\
\text { (Polysomnograph } \\
\text { y), } \\
\text { Subjective sleep } \\
\text { quality (visual } \\
\text { analog scale), } \\
\text { Serum melatonin } \\
\text { concentration }\end{array}$ & $\begin{array}{l}\text { Penggunaan melatonin lebih baik dalam } \\
\text { meningkatkan kualitas tidur dibandingkan } \\
\text { dengan penggunaan earplugs dan eye } \\
\text { masks. } \\
\text { Serum melatonin meningkat pada pasien } \\
\text { yg menggunkan melatonin dibandingkan } \\
\text { intervensi yang lain }\end{array}$ \\
\hline
\end{tabular}


2. Earplug,Fateme Neyse, et.al., (2011) meneliti 60 pasien jantung di CCU usia> 18 tahun di Tehran Iran dengan RCT pre-post test design. 60 pasien dibagi menjadi 2, 30 dipasang earplugs, 30 tanpa earplugs, tidak ada yang drop out. Pemasangan earplugs dilakukan setiap malam selama pasien di rumah sakit sampai pulang. Kualitas tidur diukur menggunakan PSQI sebelum pemasangan earplugs dan di akhir rawat inap (post test). Hasil penelitian menunjukkan penggunaan earplugs dapat meningkatkan kualitas tidur ( $p$ value $<0.05$ ) pada kelompok perlakukan dibandingkan dengan kelompok kontrol.

3. Eye Mask Dan Earplug, Yazdannik, et.al. (2014) melakukan penelitian pada 50 pasien ICU usia >18 tahun di Isfahan dengan RCT cross over design. Responden dibagi menjadi 2 grup, tidak ada yang drop out. Pengukuran kualitas tidur dilakukan setelah kedua grup selesai dilakukan intervensi dengan menggunakan VSH. Hasil penelitian menunjukkan bahwa perlakuan memiliki efek positif pada efektifitas tidur dan terdapat perbedaan yang signifikan $(\mathrm{p}<0.001)$ antara kelompok perlakuan dan kelompok kontrol. Tahun 2015, Dave, et. al. Melakukan penelitian yang sama pada 50 pasien ICU di India usia 2070 tahun dengan desain yang sama (RCT cross over design), namun menggunakan alat ukur yang berbeda yaitu RSCQ (Richards Campbell Sleep Questionnaire). Responden dibagi 2 grup, tidak ada yang drop out. Hasil penelitian menunjukkan terdapat perbedaan kualitas tidur yang signifikan pada saat diberikan perlakuan dengan tanpa perlakuan $(\mathrm{p}<0.001)$.

4. Controlling Night-Time Noise, Penelitian dilakukan oleh Shu-Yen Li, et al. (2011) dengan desain quasi-eksperimen pada 60 pasien bedah usia >18 tahun di ICU di Taiwan. 60 pasien dibagi menjadi 2, 30 kelompok perlakuan diberikan the sleep care guidelines for noise and light reduction, 30 kelompok kontrol menerima perawatan rutin. 5 pasien drop out karena lost of follow up sehingga pada akhir penelitian kelompok perlakuan 28 pasien dan kelompok kontrol 27. Alat ukur yang digunakan yaitu SICUQ (Sleep in The Intensive Care Unit Questionnaire), RSCQ, dan decibel meter yang digunakan untuk memonitor tingkat kebisingan dari pukul 11:00 p.m. - 07.00 a.m. secara terus - menerus pada bedside dan nursing station di Surgical ICU. Skor RSCQ menunjukkan bahwa kualitas tidur pada kelompok perlakuan lebih tinggi dibandingkan kelompok kontrol $(\mathrm{p}<0.05)$.

5. Kombinasi Eye Mask, Earplug, Dan Musik, Penelitian dilakukan Min-Jung Ryu, et al. (2011) pada 58 pasien PTCA (Percutaneous Transluminal Coronary Angipgraphy) usia $\geq 20$ tahun di CCU. Penelitian menggunakan desain RCT, dibagi menjadi 2, 29 pasien (kelompok perlakuan) dipasang earplugs + eyeshield + musik yang memicu tidur selama 52 menit pada awal pukul 10 malam (hanya 1 malam), 1 pasien drop out karena mengonsumsi obat tidur, 29 pasien (kelompok kontrol) dipasang earplugs+eyeshield tanpa musik, 1 orang drop out karena dipindah ke ruangan. Pagi hari pkl 07.00 dilakukan pengukuran kualitas tidur menggunakan VSH dan kuantitas tidur diukur menggunakan kuesioner yang berisi tentang jumlah total jam tidur. Hasil penelitian menunjukkan kelompok perlakuan earplugs + eyeshield + musik mengalami peningkatan kualitas $(\mathrm{p}=0.001)$ dan kuantitas $(\mathrm{p}=0.002)$ tidur secara signifikan dibandingkan tanpa musik pada kelompok kontrol. Rong-Fang $\mathrm{Hu}$, et.al., (2015) melakukan penelitian $R C T$ pada 45 pasien ICU usia $\geq 40$ tahun, dibagi menjadi 2; 25 kelompok perlakuan (mengombinasikan antara earplugs, eye mask, dan pemberian musik selama 30 menit pada pkl. 21.00 - 06.00) dibandingkan dengan 25 kelompok kontrol yang tidak dilakukan intervensi apapun. 5 responden kelompok perlakuan drop out; 2 mengalami komplikasi post operasi serius, 2 menolak memakai earplugs+eye mask, dan 1 menolak diperdengarkan musik. Kualitas tidur subyektif diukur hari ke 1 atau ke 2 setelah pindah dari ICU menggunakan RCSQ. Selain itu kadar melatonin dan kortisol juga dievaluasi sebelum operasi dan sesudah operasi. Hasil penelitian menunjukkan penggunaan earplugs+eye mask+musik membantu meningkatkan persepsi tidur dibuktikan dengan subjective sleep quality lebih tinggi pada kelompok intervensi dibandingkan dengan kelompok kontrol ( $p$ value < 0.05) dan perlakuan ini tidak mempengaruhi oleh level melatonin dan kortisol di malam hari. Hua Wei Huang, et.al. (2015) melakukan penelitian yang sama namun ditambahkan perlakuan dengan pemberian melatonin oral dengan $R C T$ - cross over design yang dilakukan pada 40 pasien ICU usia $>18$ tahun. Proses perlakuan dibagi dalam dua tahap, tahap pertama dibagi 2 kelompok 
(20:20) kemudian tahap kedua dibagi menjadi 4 (10:10:10:10) yang diberikan intervensi yang berbeda. Alat ukur yang digunakan meliputi; PSG (Polysomnography), Subjective sleep quality (visual analog scale), dan Serum melatonin concentration.

Hasil penelitian ini menunjukkan bahwa penggunaan melatonin lebih baik dalam meningkatkan kualitas tidur dibandingkan dengan penggunaan earplugs maupun eye mask. Hasil evaluasi respon responden pada pemakaian eye mask dan earplugs didapatkan bahwa eye mask lebih nyaman, mudah, dan lebih efektif dibandingkan dengan earplugs.

Literatur review ini mengidentifikasi 5 intervensi untuk meningkatkan kualitas tidur pasien di ICU/ CCU meliputi; pemakaian eye mask, earplugs, terapi musik, mengurangi pencahayaan mengurangi kebisingan lingkungan pada jam tidur, pengalihan jadwal perawatan di luar jam tidur, serta kombinasi earplugs + eyemask+musik dengan/ tanpa melatonin, yang semuanya terbukti efektif untuk meningkatkan kualitas tidur. Earplugs dilaporkan beberapa responden mengalami ketidaknyamanan dalam pemakaian. Dari segi desain, 9 jurnal menggunakan RCT dan 2 quasi ekperimen sehingga review ini cukup kuat berdasar level of evidence. Sedangkan dari segi alat ukur, 10 jurnal menggunakan alat ukur subjektif dan 1 jurnal yang menggunakan PSG (Polysomnography) yang menggunakan responden sehat dalam ICU setting. PSG merupakan gold standard untuk pengukuran kualitas tidur secara objektif dengan akurasi yang tinggi, namun tidak mudah diaplikasikan pada pasien di ICU karena mahal dan membutuhkan manipulasi yang bisa mengganggu proses perawatan di ICU/CCU.

Hasil review menunjukkan bahwa semua perlakuan yang diberikan (eye mask, earlugs, mengurangi pencahayaan, mengurangi kebisingan, mengalihkan jadwal perawatan di luar jam tidur, maupun kombinasi earplugs+eyemask+musik) dapat meningkatkan kualitas tidur secara subyektif. Hasil review hanya bisa diterapkan pada pasien ICU / CCU dewasa yang sadar, non komplikatif, dan kooperatif sehingga tidak bisa digunakan pada pasien yang mengalami penurunan kesadaran, gelisah, atau menggunakan ventilator. Selain itu juga belum bisa diterapkan pada karakteristik usia yang berbeda dan ruangan rawat inap yang lain.

\section{KESIMPULAN}

Tidur merupakan salah satu kebutuahn dasar manusia. Gangguan tidur sering terjadi pada pasien yang dirawat di CCU maupun ICU. Literatur review ini mengidentifikasi 5 intervensi untuk meningkatkan kualitas tidur pada pasien ICU/ CCU meliputi; pemakaian eye mask, earplugs, terapi musik, mengurangi pencahayaan dan kebisingan lingkungan pada jam tidur, pengalihan jadwal perawatan di luar jam tidur malam, serta kombinasi eyemask+earplugs+musik dengan/ tanpa melatonin, yang semuanya terbukti efektif untuk meningkatkan kualitas tidur. Hasil review disimpulkan tindakan yang paling efektif dalam meningkatkan kualitas tidur untuk diaplikasikan secara lokal yaitu menurunkan pencahayaan dan kebisingan, serta pengalihan jadwal perawatan di jam tidur karena mudah, aman, dan tidak membutuhkan biaya. Namun hanya bisa diterapkan pada pasien ICU/ CCU dewasa yang sadar, non komplikatif, dan kooperatif sehingga belum bisa digeneralisasikan pada karakteristik usia, kondisi, dan setting yang berbeda seperti di ruang rawat inap selain ICU/CCU. Diperlukan penelitian lanjutan pada pasien diluar ICU/CCU dengan jumlah sampel yang lebih banyak, karakteristik usia dan kondisi yang berbeda, durasi perlakuan lebih lama, serta menggunakan alat ukur obyektif seperti polysomnography.

\section{DAFTAR PUSTAKA}

Babaii, A., Adib-Hajbaghery, M., \& Hajibagheri, A. (2015). Effect of Using Eye Mask on Sleep Quality in Cardiac Patients: A Randomized Controlled Trial. Nursing and Midwifery Studies, 4(4), e28332. Diakses 13 Oktober 2016, dari Pubmed database.

Daneshmandi, M., Neiseh, F., Sadeghi Shermeh, M., \& Ebadi, A. (2012). Effect of Eye Mask On Sleep Quality In Patients With Acute Coronary Syndrome. Journal of Caring Sciences, 1(3), 135-43. Diakses 13 Oktober 2016, dari Pubmed database.

Dave, K., Qureshi, A., \& Gopichandran, L. (2015). Effect of Earplugs and Eye Masks on Perceived Quality of Sleep 
during Night among Patients in Intensive Care Units. Asian Journal Nursing Education and Research, 5(3), 319-322. Diakses 01 Desember 2016, dari Proquest database.

Huang, H.-W., Zheng, B.-L., Jiang, L., Lin, Z.T., Zhang, G.-B., Shen, L., \& Xi, X.-M. (2015). Effect Of Oral Melatonin And Wearing Earplugs And Eye Masks On Nocturnal Sleep In Healthy Subjects In A Simulated Intensive Care Unit Environment: Which Might Be A More Promising Strategy For ICU Sleep Deprivation? Critical Care (London, England), 19(1),124. Diakses 13 Oktober 2016, dari BioMed Central database.

Hu, Rong Fang, Jiang, X.Y., Hegadoren, K.M., \& Zhang, Y.H. (2015). Effect Of Earplugs and Eye Mask Combine With Relaxing Music On Sleep, Melatonin, And Cortisol Level in ICU patients: a randomized contolled trial. Critical Care. 19,115. Diakses 25 September 2016, dari Biomed Central database.

Leland, N. E., et.al. (2014). What Is Occupational Therapy's Role In Addressing Sleep Problems Aming Older Adults. OTJR: Occupation, Participation and Health. 34(3). Diakses 25 September 2016, dari Sage Publication database.

Li, S.Y., Wang, T.J., Vivienne Wu, S.F., Liang, S.Y., \& Tung, H.H. (2011). Efficacy of Controlling Night-Time Noise and
Activities to Improve Patient's Sleep Quality in a Surgical Intensive Care Unit. Journal Of Clinical Nursing, 20, 396407. Diakses 01 Desember 2016, dari Ebscho database.

Mashayekhi, F., Arab, M., Pilevarzadeh, M., Amiri, M., \& Rafiei, H. (2013). The Effect of Eye Mask on Sleep Quality in Patients of Coronary Care Unit. Sleep Science, 6 (3), 108-111. Diakses 2 November 2016, dari Google Scholar database.

Neyse, F., Daneshmandi, M., Sharme, M. S., \& Ebadi, A. (2011). The effect of earplugs on sleep quality in patients with acute coronary syndrome, Journal Of Caring Sciences, 4(3), 127-134. Diakses 13 Oktober 2016, dari Pubmed database.

Ryu, M.J., Park, J.S., \& Park, H. (2011). Effect of Sleep-Inducing Music on Sleep in Persons with Percutaneous Transluminal Coronary Angiography in the Cardiac Care Unit. Journal of Clinical Nursing, 21, 728-735. Diakses 01 Desember 2016, dari Ebscho database.

Yazdannik, A.R., Zareie, A., Hasanpour, M., \& Kashefi, P. (2014). The Effect of Earplugs and Eye mask On Patients Perceived Sleep Quality in Intensive Care Unit. Iranian Journal Of Nursing and Midwifery Research, 19(6), 673-678. Diakses 01 Desember 2016, dari Ebscho database 